Update Cancer Ther. 2009 April 1; 3(3): 109-118. doi:10.1016/j.uct.2009.01.001.

\title{
The MET axis as a therapeutic target
}

\author{
Martin Sattler ${ }^{1,2}$ and Ravi Salgia ${ }^{3}$ \\ ${ }^{1}$ Department of Medical Oncology, Dana-Farber Cancer Institute 44 Binney Street, Boston, MA \\ 02115 \\ ${ }^{2}$ Brigham and Women's Hospital, Harvard Medical School 44 Binney Street, Boston, MA 02115 \\ ${ }^{3}$ Department of Medicine, Section of Hematology/Oncology, Pritzker School of Medicine, University \\ of Chicago, 5841 South Maryland Ave., Chicago, IL 60637
}

\begin{abstract}
The MET receptor tyrosine kinase and its ligand hepatocyte growth factor (HGF) have been implicated in transformation of a variety of malignancies. Chronic or dysregulated activation of the MET/HGF pathway may lead to increased cell growth, invasion, angiogenesis, and metastasis, reduced apoptosis, altered cytoskeletal functions and other biological changes. It has been suggested that ligand activated MET stimulation can be sufficient for a transforming phenotype. In addition, amplification and activation mutations (germline and/or somatic) within the tyrosine kinase domain, juxtamembrane domain, or semaphorin domain have been identified for MET. MET gain-of-function mutations lead to either deregulated or prolonged tyrosine kinase activity, which are instrumental to its transforming activity. A number of therapeutic strategies targeting ligand-dependent activation or the kinase domain have been employed to inhibit MET. The different structural requirements for activation of signaling events and biological functions regulated by MET will be summarized. Therapeutic targets and current pre-clinical and clinical approaches will be described. Targeting the HGF/MET pathway, alone or in combination with standard therapies, is likely to improve present therapies in MET-dependent malignancies.
\end{abstract}

\section{Keywords}

MET; hepatocyte growth factor; signal transduction; targeted therapy; inhibitors

\section{Introduction}

The receptor tyrosine kinase c-MET (hereafter MET) is normally activated by ligation through its natural ligand HGF (hepatocyte growth factor), also known as scatter factor. HGF is a member of the plasminogen-related growth factor family and was originally identified as a growth factor for hepatocytes and as a fibroblast-derived cell motility or scatter factor [1-3]. HGF is secreted as a precursor that is proteolytically cleaved to a disulfide-linked heterodimer, predominantly produced by mesenchymal cells. HGF consists of 6 domains (N-terminal domain (n), four kringle domains (k1-k4), and a C-terminal domain (sp, structurally similar to the catalytic domain of serine proteinases)). There is a 2:2 stoichiometry of HGF binding to MET. HGF has been shown to bind to the sema domain [4,5]. The MET sema domain folds into a seven $\beta$-propeller structure, where blades 2 and 3 bottom face bind to the HGF $\beta$-chain active site region. 
The gene for human MET is located on chromosome 7 (7q21-q31) and encodes a single precursor that is post-transcriptionally digested and glycosylated, forming a $50 \mathrm{kDa}$ extracellular $\alpha$-chain and a transmembrane $140 \mathrm{kDa} \beta$-chain, which are then linked by disulfide bonds. MET is related to Ron and Sea kinases, which have extracellular structures related to the semaphorin receptor (or plexin) family [6,7]. The MET $\beta$-chain contains structural homologous domains shared with other proteins, including a Sema domain, a PSI domain (found within plexins, semaphorins and integrins), four IPT repeats (found within immunoglobulins, plexins and transcription factors), a transmembrane domain, a juxtamembrane (JM) domain, a tyrosine kinase domain and a carboxy-terminal tail region (Figure 1). MET is mainly expressed but not limited to epithelial cells. The MET protooncogene was originally identified as the transforming fusion oncogene Tpr-MET in an osteosarcoma cell line that had been chemically mutagenized with $\mathrm{N}$-methyl- $\mathrm{N}^{\prime}$-nitro-Nnitrosoguanidine in vitro [8]. The Tpr-MET translocation fuses the $T p r$ (chromosome 1) gene with the MET kinase gene (chromosome 7). The Tpr sequence provides two leucine zipper domains, which facilitate oligomerization and substitute for HGF stimulated activation. This structural change results in constitutive activation of its kinase activity, which is required for its transforming properties [9,10]. Nevertheless, there is little evidence that this particular translocation is of clinical relevance. However, MET has been found to be overexpressed and mutated (germline and somatic) in a variety of malignancies. Activation of MET can occur by HGF ligation or through ligand-independent mechanisms, including mutations and amplifications. Biological and biochemical functions regulated by MET will be summarized, and novel approaches to the therapeutic inhibition of the MET/HGF axis will be described. Recent advances in the development of targeted therapies for tyrosine kinase oncogenes suggest that MET may be an ideal rational target in clinical therapeutics.

\section{Phosphorylation-dependent signaling of MET}

Under physiological conditions, the first step of MET activation involves ligation of the receptor by its ligand, HGF. Subsequent MET dimerization and activation of its tyrosine kinase is followed by activation of signaling cascades (see video) and terminated by activation of specific phosphatases and internalization into clathrin-coated vesicles. As part of the endosomal complex, MET is then finally degraded via the lysosomal pathway [11,12]. One of the initial events of MET activation is the phosphorylation at Y1230, Y1234, and Y1235 in the activation loop of the kinase domain, which correlates with increased tyrosine kinase activity $[13,14]$. There are multiple substrates for MET, including downstream intermediates and the kinase itself, but it should be noted that MET is also likely to be a substrate for other kinases.

An important regulatory site in MET involves Y1003 within the juxtamembrane domain, which recruits $\mathrm{Cbl}$ when phosphorylated. $\mathrm{Cbl}$ is a E3-ubiquitin ligase that facilitates ubiquitination of the MET receptor, thereby directing internalization, trafficking to late endosomes, and ultimate degradation [15]. Cbl regulates internalization by acting as an adaptor for endophilin, an enzyme involved in membrane curvature [16,17]. Cbl itself requires dimerization through the ubiquitin-associated (UBA) domain for its activity and tyrosine phosphorylation by MET [18]. Ubiquitinated MET interacts with its substrate Hrs (HGF-regulated tyrosine kinase substrate) to retain the ubiquitinated receptor within the bilayered clathrin coat and facilitate internalization [19]. Ubiquitination-deficient MET containing the Y1003F mutation does not show altered MET internalization but increased stability of MET due to decreased lysosomal receptor degradation and thus further recycling to the membrane and signaling as well as oncogenic activation [15].

Additional phosphorylation sites in MET lead to the recruitment of signaling proteins and mediate downstream signaling events, but may also include non-tyrosine residues that can alter 
MET function. For example phosphorylation at S985 negatively regulates MET [20]. The unique multi-substrate docking site Y1349 and Y1356 can lead to the recruitment of a variety of proteins when phosphorylated, including SH2 (Src homology-2) domains, PTB (phosphotyrosine binding) domains, and MBD (MET binding domain) containing signaling proteins $[21,22]$. Activation of phosphatidylinositol-3'kinase (PI3K) is regulated through the multi-substrate binding site of MET, mainly indirectly through recruitment of the scaffold Gab1 and binding of p85PI3K to this protein [21,23]. Cell morphogenesis is mediated in part through Y1365 [24]. Additional post-translational modifications and domain structures are likely to contribute to the biological functions induced by the activated MET receptor.

\section{Biological activities of activated MET}

The cellular context is thought to determine the outcome of HGF induced MET activation and may trigger a variety of responses, including growth, transformation of normal cells to malignant cells, cell motility, invasion, metastasis, epithelial to mesenchymal transition (EMT), angiogenesis, wound healing, and tissue regeneration. Thus it is not surprising that mice with MET gene disruption have embryonic lethality with severe defects in liver and placenta development and this is quite similar to mice with a disruption of the HGF gene. HGF and MET likely have a broader role in morphogenesis and growth in multiple embryonic tissues, including the nervous system [25-28]. There may be differences in the regulation of MET activities in oncogenic transformation compared with normal MET signaling. Nevertheless, overexpression of MET has been shown to be sufficient for transformation of normal osteoblasts [29]. MET overexpression resulted in the conversion of primary human osteoblasts into transformed osteosarcoma cells in vitro, causing an osteosarcoma-like disease in vivo. This process was fully dependent on MET expression and functional activation. Overexpression of MET in hepatocytes is sufficient to induce hepatocellular carcinoma in transgenic mice [30], and overexpressing HGF in MET containing tumor cells, resulted in pulmonary metastases in transgenic mice [31]. HGF-dependent autocrine MET activation has been found in human primary and metastatic tumors, including breast cancer, glioblastoma, osteosarcoma and melanoma [32-35]. In lung cancer, MET overexpression is associated with higher pathological tumor stage and worse outcome. [36-38]. MET was overexpressed in all eleven non-small cell lung cancer (NSCLC) cell lines studied, and in 34 of 47 adenocarcinomas and 20 of 52 squamous cell carcinomas [36]. The level of overexpression can reach 2 to 10times the level compared to adjacent normal lung tissue in 25\% of NSCLC tumors, and HGF levels can be 10 to 100 -fold increased in carcinoma samples as compared to adjacent normal tissue [39]. Similar to MET, higher levels of HGF were associated with a poorer prognosis in NSCLC [40]. In addition, HGF overexpression in the airways of transgenic mice increases susceptibility to carcinogen induced lung cancer [41]. Thus, there is a correlation between abnormal expression of either MET or HGF and cancer susceptibility or development and this may include a variety of cancers [42].

Next to the induction of cell growth and reduced apoptosis, the most profound biological effects of activated MET include altered cytoskeletal function. The ability of HGF to induce growth and scattering in hepatocytes has been well described [1-3]. Cell scattering is a cytoskeleton regulated process that involves cell spreading, cell-cell dissociation, and cell migration. In H358 lung adenocarcinoma cells spontaneous cell scattering can be induced by HGF expression, which is accompanied by increased soft-agar colony formation and increased capacity to form xenograft tumors in immune-deficient mice [43]. In SCLC, HGF stimulation of MET enhances cell motility, a process that involves the formation and retraction of filopodia/ lamellopodia, changes in actin formation, and cell migration [44]. Ligand-dependent and independent MET signaling also increases the motility of epithelial cells [45]. The mechanism by which HGF stimulation of MET leads to increased motility, migration, and invasion is not well understood. In renal epithelial cells PI3K activity is required for HGF-induced mito-, 
moto-, or morphogenesis, and inhibition of its activity decreased branching formation on collagen and chemotaxis [46].

\section{MET is a target of mutations and amplifications}

The MET receptor is mainly expressed by epithelial cells but can also be found in a variety of human cancer cell lines or tumor tissue. In human gastric carcinoma MET-mediated tumorigenesis is thought to be a result of gene amplification, via the break-fusion-bridge (BFB) mechanism [47]. Approximately 10-20\% of gastric carcinomas have MET amplification [48], and gastric cancer cell lines show increased susceptibility to MET kinase inhibition [49]. Interestingly, there is a strong correlation between MET amplification and expression of paxillin, a focal adhesion protein. Paxillin is down-stream of MET and involved in the regulation of cytoskeletal functions. It is also a target of somatic mutations in $9 \%$ of NSCLC (18 of 191) [50]. It would now be intriguing to evaluate the potential prognostic value of paxillin expression in MET-dependent cancers. Also, it has recently been suggested that MET amplification may lead to EGFR inhibitor (gefitinib) resistance of EGFR-dependent lung tumors in an in vitro model [51]. However, these results have not been confirmed in the human disease [52], emphasizing the need to cautiously interpret data obtained in vitro and using relatively small data sets from patients receiving tyrosine kinase inhibition therapy. In addition to amplification, MET can also be activated by missense mutations. Due to the essential role of the MET kinase domain in MET-dependent transformation, efforts initially had been directed on identifying mutations in the MET kinase domain. The majority of tyrosine kinase domain activating mutations in MET have been described in sporadic papillary renal carcinomas (somatic) and hereditary papillary renal cell carcinomas (germline), resulting in an increase in kinase activity [45,53]. Recent mutational analyses have included all exons coding for the MET kinase.

\section{MET mutations in the juxtamembrane (JM) domain}

One of the first germline mutations found to be associated with the MET JM domain was the P1009S in a patient with gastric carcinoma. Even though the P1009S mutation does not induce ligand-independent activation of MET, it showed increased persistent response to HGF stimulation when expressed in fibroblasts [54]. It is possible that some of these JM domain variations may affect cancer risk in carriers. This is also supported by the occurrence of a specific gain-of-function germline mutation of MET (G966S occurs at frequency of 74\%) in Rottweiler dogs specifically [55]. These dogs are thought to be predisposed to certain cancers, including osteosarcoma, lymphoma, and histiocytic sarcoma. In contrast, the best characterized JM domain gain-of-function mutations occur in the Flt3 receptor tyrosine kinase. These Flt3 $\mathrm{JM}$ domain mutations have been identified as regulators of catalytic activity and are present in about $20 \%$ of adult acute myeloid leukemias (AML) [56]. JM domain mutations of MET appear to be rare in AML and only recently has a T1010I mutation been identified [57]. This mutation has been found previously in hereditary papillary renal cell carcinoma and in a patient with breast cancer [54,58]. MET-T1010I is not associated with full activation of the MET kinase activity but athymic nude mice injected with mutant MET in NIH3T3 cells form tumors faster than wild-type MET expressing cells [54]. Furthermore, in 126 patients with adenocarcinomas, R988C, T1010I and T1010A germline mutations were identified and the R988C variation was shown to be important in lung tumorigenesis of SWR/J mouse strain [59]. The T1010I mutation is also found in the human mesothelioma cell lines H513 and H2596 [60]. Similarly, MET JM domain mutations in tissue samples and cell lines from small cell lung cancer (SCLC), including R988C, T1010I and S1058P, are likely to contribute to enhanced tumorigenicity, cell migration, and phosphorylation of protein in SCLC [61]. Interestingly, this phenotype may be in part mediated through increased levels of reactive oxygen species (ROS) that have been found to be associated with the R988C and T1010I variants [62]. ROS do not only play an 
important role in lung cancer and MET signaling but may have a broader impact on signaling in cancer [63]. Further, the MET-R988C mutation was also identified in melanoma cell lines in addition to a N948S MET missense mutation in tumor tissue. Interestingly, the MET receptor was phosphorylated at the Y1003 activation site in 21\% of human melanomas [64]. The Y1003 JM tyrosine is crucial for MET activity and when replaced by phenylalanine (Y1003F), a loss of ubiquitination of the MET receptor and transformed activity in fibroblast and epithelial cells occurs [65].

\section{MET mutations in the semaphorin (sema) domain}

The sema domain within MET is located in the extracellular portion. In MET, the sema domain is encoded by exon 2, and binds specifically to HGF. The three dimensional conformation of the HGF and heparin-binding sites of MET have been established by deletion mutagenesis of the kinase [66]. The extracellular ligand-binding domain in the MET ectodomain was identified as adopting a seven-blade $\beta$-propeller fold for the sema domain of MET, providing important structural information for the development of targeted therapies $[4,66]$. The unique role of the sema domain in the functional regulation of MET would also predict it to be a potential target of activating mutations in MET dependent cancers. Indeed, 7\% of mesothelioma patients (3 out of 43) were found to have mutations (N375S, M431V, and N454I) within the sema domain [60]. The functional role of these MET mutations in transformation still needs to be evaluated.

\section{MET as a target for cancer prevention}

Whereas mutant MET has already been implicated in transformation, the role of its cellular homolog as a tumor-promoting factor is just beginning to emerge. In Kras ${ }^{\mathrm{LA} 1}$ mice, containing the somatic G12D mutation in K-ras, MET kinase activity is required for lung cancer development. Normally, Kras ${ }^{\mathrm{LA} 1}$ mice develop pre-malignant lesions, including adenomatous alveolar hyperplasia and adenomas that eventually develop to adenocarcinomas [67]. Injection of the mice with the MET inhibitor PHA-665752 inhibits the development of lung cancer, suggesting that MET signaling cooperates with K-ras.G12D in this process [68]. Even though the mutational status of MET in these adenocarcinomas is not known, it was suggested that elevated levels of HGF lead to ligand-dependent stimulation of MET. Activity of MET was required for progression as well as maintenance of the tumor. In humans, transformation in NSCLC is driven by a variety of mutations with up to $30 \%$ of patients with mutant K-ras [69]. It will now be interesting to see if in these at least some requirement for active MET is preserved.

\section{C. elegans model for the role of MET mutations in lung cancer}

Gain-of-function mutations in MET are thought to frequently act in combination with additional mutations in a variety of key cellular genes to contribute to a complex transforming phenotype. In addition, environmental factors may regulate the function of MET. This may be in particular true for the interaction of MET and cigarette smoke (nicotine). Recent evidence suggests that the nematode $C$. elegans is an excellent model to study the impact of nicotine on a whole organism, with analogous biochemical addiction compared to humans. Nicotinedependent behavior is mostly regulated through the nicotinic acetylcholine receptors and this pathway is functional in C. elegans. The nematodes exhibit behavioral responses to nicotine that parallel those observed in mammals, including acute response, tolerance, withdrawal, and sensitization. In addition, the response to nicotine appears to require TRPC (transient receptor potential canonical) channels as well. Nematodes without these channels do not respond to nicotine [70]. This is of interest, because recent evidence suggests that transforming MET leads to developmental abnormalities in C. elegans and this phenotype can be amplified by nicotine [71]. Transgenic C. elegans that harbor the MET.R988C and MET.T1010I mutations that occur frequently in lung cancer, but not wild-type MET, have low fecundity and abnormal vulval 
development characterized by hyperplasia. Importantly, exposure of MET mutant transgenic nematodes to nicotine resulted in significantly enhanced abnormal vulval development, fecundity and locomotion. It should be noted that this phenotype in C. elegans cannot truly be a reflection of a potential mammalian phenotype. Instead, this whole organism in vivo system allows a rapid screen for the functional aspects of mutant forms of MET detected in lung cancer or other malignancies. Transgenic C. elegans models have gained popularity for the assessment of the role of cancer specific gene mutations in the context of a whole organism, but may be particularly suitable in the context of MET mutations.

\section{Inhibition of the MET pathway in tumors}

With the advent of clinically successful small molecule tyrosine kinase inhibitors the race for identifying similar approaches in tumors with activated MET kinase has picked up considerable speed. In addition to small molecule tyrosine kinase inhibitors, deregulated MET activation in tumors has led to the development of multiple approaches for targeted therapies. Not only have MET kinase inhibitors been identified, but also approaches that disrupt the interaction of MET with its natural ligand HGF or the expression of MET itself have been developed (Figure 2). There is increasing evidence that MET has a broader role in a diverse set of tumors than previously thought. It is expected that molecularly targeted therapy against MET will lead to dramatic inhibition of cancer growth and metastasis in these cancers.

\section{Targeting MET kinase activity with small molecule inhibitors}

Small molecule inhibitors have the advantage of improved bioavailabilty in contrast to larger peptide inhibitors, such as a carboxy-terminal MET peptide, that has shown inhibitory activity in vitro [72] but clinical efficacy may be limited. There are a variety of novel MET kinase inhibitors under pre-clinical and clinical evaluation [52,73-76] with better target profiles than the first generation broad-spectrum MET inhibitor K252a, which can also inhibit serine/ threonine kinases [77]. Importantly, lessons learned from imatinib mesylate suggest that drug resistance may occur over time, limiting the efficacy of the drug [78]. As one of the first new generation small molecule MET inhibitors, SU11274 was shown to be effective in MET transformed cell lines or lung cancer cells with activated MET, but not in cells with activated ABL, JAK2 or PDGFRß kinases [75]. The inhibitor reduced MET kinase activity, cell growth, induced G1 cell cycle arrest and apoptosis, as well as inhibited MET-dependent signaling. Currently, there are additional MET inhibitors under development with the goal of identifying drugs that achieve high specificity at low drug concentrations and suitable bioavailability. Additional MET inhibitors include PHA-665752 that inhibits MET dependent effects in tumor cells and causes regression of GTL-16 gastric carcinoma xenografts [73]. The multi-kinase MET inhibitor GSK1363089 (formerly XL880) has shown activity against lung adenocarcinoma cells with the drug resistant EGFR.T790M mutation and overexpressing MET, but this drug may also target VEGFR2, PDGFR $\beta$, KIT, FLT3, TIE2 and RON [52]. Also, the MET/ALK inhibitor PF-2341066 reduced MET-dependent proliferation, migration and invasion of tumor cells in vitro as well as HGF-driven angiogenesis [76]. The identification of effective inhibitors of MET tyrosine kinase activity illustrates the potential therapeutic utility of targeting for MET in cancers associated with activated forms of this kinase. There are currently eight different small molecule MET inhibitors that are at different stages in clinical development for the treatment of various cancers, including ARQ197 (ArQule), GSK1363089 (GlaxoSmithKline), JNJ38877605 (Johnson \& Johnson), MK2461 (Merck), MP470 (SuperGen), PF-02341066 and PF-04217903 (Pfizer) as well as XL184 (Exelixis) (see also Table 1). These trials have the potential to ultimately validate MET as a target and improve the outcome of patients with MET dependent cancers.

Recently phase I trial data were presented for ARQ197 [79]. Eighteen patients received doses of 100, 200, 300, and $400 \mathrm{mg}$ two times a day. Pharmacokinetics showed Cmax increased 
linearly, and two patients exhibited dose limiting toxicity of grade 3 febrile neutropenia and grade 3 palmar-plantar erythrodysesthesia and mucositis. There were lower grade toxicities of fatigue, nausea, vomiting and diarrhea. Prolonged disease stabilization was observed in 5 patients, and tumor regression was observed in a patient with metastatic gastric cancer. The initial results of a dose escalating phase I trial for MetMAb (humanized one-armed anti-MET antibody) $(1,4,10,20,30 \mathrm{mg} / \mathrm{kg})$ have also been reported. A single grade 3 dose limiting toxicity was observed with pyrexia at $4 \mathrm{mg} / \mathrm{kg}$. The MetMAb antibody has a half-life and clearance of approximately 10 days and $8 \mathrm{~mL} / \mathrm{kg} /$ day respectively. Pharmacokinetics are linear in the range of $4-30 \mathrm{mg} / \mathrm{kg}[80]$.

\section{Targeting functional activation of MET by HGF}

Probably one of the most promising approaches of disrupting the potential MET activation by HGF involves the NK4 (N-terminal hairpin domain and kringle domain) protein. NK4 antagonizes HGF-mediated activation of MET and was originally identified as a proteolytic fragment of HGF, lacking its B-chain [81]. The family of NK proteins contains four variants of the HGF $\alpha$-chain, containing one (NK1) to four (NK4) kringle domains. NK4 acts as an antagonist, whereas NK1-3 proteins are weak agonists towards MET and compete for binding of HGF to the receptor. NK proteins would therefore only be efficient against autocrine or paracrine activation of the MET receptor and likely not against activating mutations within MET. NK4 protein has been extensively studied in a variety of solid tumors as well as hematologic malignancies and has been shown to be particularly effective in targeting HGFdependent angiogenesis, metastasis and growth (see also for review [82]). For example, NK4 prolonged the survival of mice in a pancreatic cancer model by inhibiting growth, invasion and disseminated metastasis [83]. NK4 was also found to reduce angiogenesis as well as affect motility and invasion of HT115 human colorectal cancer cells [84]. Additional approaches, targeting the interaction of HGF with its receptor have shown some success but have not come to full fruition. Whereas NK4 competes with HGF for binding to MET, a modified METspecific antibody that blocks HGF binding to the receptor has shown efficacy in an intracranial orthotopic xenograft model of MET-expressing glioblastoma [85]. In addition, a decoy MET receptor has been suggested to neutralize HGF-dependent MET signaling by binding and therefore neutralizing HGF activity [86,87]. Another promising strategy involves targeting MET with the novel CE-355621 antibody. In a mouse xenograft model with subcutaneous U87-MG glioblastoma-astrocytoma cells, CE-355621 significantly reduced glucose uptake and tumor volume [88]. The human monoclonal antibody AMG102 against HGF [89] prevents receptor binding and is currently in clinical trials against malignant glioma, renal cell carcinoma, gastric and esophagogastric junction cancer (see Table 1). Humanized monoclonal antibodies have been successfully used in solid tumors, e.g. the EGFR targeted antibody cetuximab in colorectal cancer as well as lung cancer [90]. An unfortunate drawback of this approach is the considerable cost associated with the production of these antibodies, which is high in contrast to small molecule drugs. However, one can envision that any of these approaches may show little efficacy in cancers with activating mutations of MET that do not require ligand binding.

\section{Targeting MET expression}

MET expression can be targeted at the RNA level with MET-specific ribozymes and RNA interference (RNAi) or at the level of protein maturation. Ribozymes are RNA-based enzymes that bind to and cleave RNA molecules in a sequence-specific manner. Similarly, knockdown by RNA inerference (RNAi), is a sequence specific approach, involving microRNA (miRNA), small hairpin (shRNA) or small interference RNA (siRNA), leading to the specific silencing of the targeted RNA. Although promising, neither approach has come to fruition and it is uncertain if protein levels can be sufficiently reduced in clinical applications. In vivo, the miRNAs miR-1/206, miR-23, miR-34, and miR-199a are predicted to target MET [91]. In 
vitro, MET-positive colorectal carcinomas have been targeted with ribozymes, reducing kinase activity of MET by up to 60-90\% [92]. In the MM.1S multiple myeloma cell line, MET ribozymes and knockdown with MET siRNA demonstrated a role of this kinase in survival signaling [93]. MET targeted RNAi has also been successfully used in human cancer cell lines, including non-small cell lung cancer, breast cancer, prostate cancer, sarcoma, glioblastoma and gastric cancer cells $[74,94,95]$. Reduction of MET expression led to cell cycle arrest, reduced transformation, increased apoptosis, or inhibition of responsiveness to HGF stimulation. Hopefully, with better means to apply MET RNAi in vivo, this approach may be a suitable alternative to small molecule drug intervention in the treatment of MET-dependent cancers.

A rather non-specific way of targeting MET protein expression is through inhibition of the heat shock protein (Hsp90) by geldanamycin or related compounds of the anisomycin antibiotic family. Hsp90 appears to be in an activated state in cancer cells and shows a high binding affinity for 17-allylaminogeldanamycin and increased ATPase activity, which regulates Hsp90 chaperone function [96]. Geldanamycins are active against MET in SCLC cells, leading to reduced growth and viability [44]. They also block transformation of NIH3T3 cells expressing activating mutations or coexpressing HGF and MET [97]. In vitro, Geladanmycins also inhibit MET dependent scattering and invasion [98]. Since Hsp90 is not exclusively targeting MET, it is expected that a variety of other proteins are affected in their maturation and expression as well.

\section{Conclusion}

MET receptor tyrosine kinase is uniquely involved in cell proliferation, anti-apoptosis, cell motility/migration, invasion, metastasis and angiogenesis. MET can be overexpressed, mutated, or amplified in a large number of cancers. The ligand HGF can also be involved in activating MET through autocrine, juxtacrine, paracrine, or endocrine effects. MET has long been touted to be an essential therapeutic target in primary and metastatic tumors. Through various discovery strategies, a number of inhibitors have come to clinical fruition, and with a potential for a large number of cancers responding to these inhibitors. It would be useful for the future to start considering combinational strategies with surgery, radiation, and/or chemotherapy (or other novel targeted therapies) in the appropriate settings. The role of MET in prevention also needs to be further defined. Ultimately, MET/HGF axis plays a crucial role in normal homeostasis as well as tumorigenesis. Thus, targeting MET/HGF pathway may be an important addition to our armamentarium for anti-neoplastic therapy.

\section{Supplementary Material}

Refer to Web version on PubMed Central for supplementary material.

\section{Acknowledgments}

This work is supported in part by National Institutes of Health grants (CA134660-01, M.S.) and (CA100750-04, CA125541-02, and CA129501-01A1 R.S.), and grants by the Mesothelioma Applied Research Foundation (Jeffrey P. Hayes Memorial Grant), V-Foundation (Guy Geleerd Memorial Foundation) (R.S.), the U.S. Department of Defense and the Adams Barr Program in Innovative Cancer Research (M.S.).

\section{References}

1. Gohda E, Tsubouchi H, Nakayama H, Hirono S, Takahashi K, Koura M, et al. Human hepatocyte growth factor in plasma from patients with fulminant hepatic failure. Exp Cell Res 1986;166:139-50. [PubMed: 3527727] 
2. Nakamura T, Nawa K, Ichihara A, Kaise N, Nishino T. Purification and subunit structure of hepatocyte growth factor from rat platelets. FEBS Lett 1987;224:311-6. [PubMed: 3319692]

3. Stoker M, Gherardi E, Perryman M, Gray J. Scatter factor is a fibroblast-derived modulator of epithelial cell mobility. Nature 1987;327:239-42. [PubMed: 2952888]

4. Gherardi E, Sandin S, Petoukhov MV, Finch J, Youles ME, Ofverstedt LG, et al. Structural basis of hepatocyte growth factor/scatter factor and MET signalling. Proc Natl Acad Sci U S A 2006;103:404651. [PubMed: 16537482]

5. Stamos J, Lazarus RA, Yao X, Kirchhofer D, Wiesmann C. Crystal structure of the HGF beta-chain in complex with the Sema domain of the Met receptor. Embo J 2004;23:2325-35. [PubMed: 15167892]

6. Comoglio PM, Boccaccio C. The HGF receptor family: unconventional signal transducers for invasive cell growth. Genes Cells 1996;1:347-54. [PubMed: 9135079]

7. Maestrini E, Tamagnone L, Longati P, Cremona O, Gulisano M, Bione S, et al. A family of transmembrane proteins with homology to the MET-hepatocyte growth factor receptor. Proc Natl Acad Sci U S A 1996;93:674-8. [PubMed: 8570614]

8. Cooper CS, Park M, Blair DG, Tainsky MA, Huebner K, Croce CM, et al. Molecular cloning of a new transforming gene from a chemically transformed human cell line. Nature 1984;311:29-33. [PubMed: 6590967]

9. Rodrigues GA, Park M. Dimerization mediated through a leucine zipper activates the oncogenic potential of the met receptor tyrosine kinase. Mol Cell Biol 1993;13:6711-22. [PubMed: 8413267]

10. Zhen Z, Giordano S, Longati P, Medico E, Campiglio M, Comoglio PM. Structural and functional domains critical for constitutive activation of the HGF-receptor (Met). Oncogene 1994;9:1691-7. [PubMed: 8183564]

11. Hammond DE, Urbe S, Vande Woude GF, Clague MJ. Down-regulation of MET, the receptor for hepatocyte growth factor. Oncogene 2001;20:2761-70. [PubMed: 11420688]

12. Teis D, Huber LA. The odd couple: signal transduction and endocytosis. Cell Mol Life Sci 2003;60:2020-33. [PubMed: 14618253]

13. Kamada M, Komori A, Chiba S, Nakao T. A prospective study of congenital cytomegalovirus infection in Japan. Scand J Infect Dis 1983;15:227-32. [PubMed: 6316478]

14. Rodrigues GA, Park M. Autophosphorylation modulates the kinase activity and oncogenic potential of the Met receptor tyrosine kinase. Oncogene 1994;9:2019-27. [PubMed: 8208547]

15. Abella JV, Peschard P, Naujokas MA, Lin T, Saucier C, Urbe S, et al. Met/Hepatocyte growth factor receptor ubiquitination suppresses transformation and is required for Hrs phosphorylation. Mol Cell Biol 2005;25:9632-45. [PubMed: 16227611]

16. Petrelli A, Gilestro GF, Lanzardo S, Comoglio PM, Migone N, Giordano S. The endophilin-CIN85Cbl complex mediates ligand-dependent downregulation of c-Met. Nature 2002;416:187-90. [PubMed: 11894096]

17. Soubeyran P, Kowanetz K, Szymkiewicz I, Langdon WY, Dikic I. Cbl-CIN85-endophilin complex mediates ligand-induced downregulation of EGF receptors. Nature 2002;416:183-7. [PubMed: 11894095]

18. Kozlov G, Peschard P, Zimmerman B, Lin T, Moldoveanu T, Mansur-Azzam N, et al. Structural basis for UBA-mediated dimerization of c-Cbl ubiquitin ligase. J Biol Chem 2007;282:27547-55. [PubMed: 17635922]

19. Bache KG, Raiborg C, Mehlum A, Stenmark H. STAM and Hrs are subunits of a multivalent ubiquitinbinding complex on early endosomes. J Biol Chem 2003;278:12513-21. [PubMed: 12551915]

20. Gandino L, Longati P, Medico E, Prat M, Comoglio PM. Phosphorylation of serine 985 negatively regulates the hepatocyte growth factor receptor kinase. J Biol Chem 1994;269:1815-20. [PubMed: 8294430]

21. Ponzetto C, Bardelli A, Zhen Z, Maina F, dalla Zonca P, Giordano S, et al. A multifunctional docking site mediates signaling and transformation by the hepatocyte growth factor/scatter factor receptor family. Cell 1994;77:261-71. [PubMed: 7513258]

22. Furge KA, Zhang YW, Vande Woude GF. Met receptor tyrosine kinase: enhanced signaling through adapter proteins. Oncogene 2000;19:5582-9. [PubMed: 11114738] 
23. Bardelli A, Longati P, Gramaglia D, Stella MC, Comoglio PM. Gab1 coupling to the HGF/Met receptor multifunctional docking site requires binding of Grb2 and correlates with the transforming potential. Oncogene 1997;15:3103-11. [PubMed: 9444958]

24. Weidner KM, Sachs M, Riethmacher D, Birchmeier W. Mutation of juxtamembrane tyrosine residue 1001 suppresses loss-of-function mutations of the met receptor in epithelial cells. Proc Natl Acad Sci U S A 1995;92:2597-601. [PubMed: 7708691]

25. Maina F, Klein R. Hepatocyte growth factor, a versatile signal for developing neurons. Nat Neurosci 1999;2:213-7. [PubMed: 10195212]

26. Bladt F, Riethmacher D, Isenmann S, Aguzzi A, Birchmeier C. Essential role for the c-met receptor in the migration of myogenic precursor cells into the limb bud. Nature 1995;376:768-71. [PubMed: 7651534]

27. Schmidt C, Bladt F, Goedecke S, Brinkmann V, Zschiesche W, Sharpe M, et al. Scatter factor/ hepatocyte growth factor is essential for liver development. Nature 1995;373:699-702. [PubMed: 7854452]

28. Uehara Y, Minowa O, Mori C, Shiota K, Kuno J, Noda T, et al. Placental defect and embryonic lethality in mice lacking hepatocyte growth factor/scatter factor. Nature 1995;373:702-5. [PubMed: 7854453]

29. Patane S, Avnet S, Coltella N, Costa B, Sponza S, Olivero M, et al. MET overexpression turns human primary osteoblasts into osteosarcomas. Cancer Res 2006;66:4750-7. [PubMed: 16651428]

30. Wang R, Ferrell LD, Faouzi S, Maher JJ, Bishop JM. Activation of the Met receptor by cell attachment induces and sustains hepatocellular carcinomas in transgenic mice. J Cell Biol 2001;153:1023-34. [PubMed: 11381087]

31. Yu Y, Merlino G. Constitutive c-Met signaling through a nonautocrine mechanism promotes metastasis in a transgenic transplantation model. Cancer Res 2002;62:2951-6. [PubMed: 12019177]

32. Tuck AB, Park M, Sterns EE, Boag A, Elliott BE. Coexpression of hepatocyte growth factor and receptor (Met) in human breast carcinoma. Am J Pathol 1996;148:225-32. [PubMed: 8546209]

33. Koochekpour S, Jeffers M, Rulong S, Taylor G, Klineberg E, Hudson EA, et al. Met and hepatocyte growth factor/scatter factor expression in human gliomas. Cancer Res 1997;57:5391-8. [PubMed: 9393765]

34. Li G, Schaider H, Satyamoorthy K, Hanakawa Y, Hashimoto K, Herlyn M. Downregulation of Ecadherin and Desmoglein 1 by autocrine hepatocyte growth factor during melanoma development. Oncogene 2001;20:8125-35. [PubMed: 11781826]

35. Ferracini R, Di Renzo MF, Scotlandi K, Baldini N, Olivero M, Lollini P, et al. The Met/HGF receptor is over-expressed in human osteosarcomas and is activated by either a paracrine or an autocrine circuit. Oncogene 1995;10:739-49. [PubMed: 7862451]

36. Ichimura E, Maeshima A, Nakajima T, Nakamura T. Expression of c-met/HGF receptor in human non-small cell lung carcinomas in vitro and in vivo and its prognostic significance. Jpn J Cancer Res 1996;87:1063-9. [PubMed: 8957065]

37. Olivero M, Rizzo M, Madeddu R, Casadio C, Pennacchietti S, Nicotra MR, et al. Overexpression and activation of hepatocyte growth factor/scatter factor in human non-small-cell lung carcinomas. Br J Cancer 1996;74:1862-8. [PubMed: 8980383]

38. Rossi G, Cavazza A, Marchioni A, Longo L, Migaldi M, Sartori G, et al. Role of chemotherapy and the receptor tyrosine kinases KIT, PDGFRalpha, PDGFRbeta, and Met in large-cell neuroendocrine carcinoma of the lung. J Clin Oncol 2005;23:8774-85. [PubMed: 16314638]

39. Siegfried JM, Weissfeld LA, Singh-Kaw P, Weyant RJ, Testa JR, Landreneau RJ. Association of immunoreactive hepatocyte growth factor with poor survival in resectable non-small cell lung cancer. Cancer Res 1997;57:433-9. [PubMed: 9012470]

40. Siegfried JM, Weissfeld LA, Luketich JD, Weyant RJ, Gubish CT, Landreneau RJ. The clinical significance of hepatocyte growth factor for non-small cell lung cancer. Ann Thorac Surg 1998;66:1915-8. [PubMed: 9930468]

41. Stabile LP, Lyker JS, Land SR, Dacic S, Zamboni BA, Siegfried JM. Transgenic mice overexpressing hepatocyte growth factor in the airways show increased susceptibility to lung cancer. Carcinogenesis 2006;27:1547-55. [PubMed: 16513678] 
42. Ma PC, Tretiakova MS, MacKinnon AC, Ramnath N, Johnson C, Dietrich S, et al. Expression and Mutational Analysis of MET in Human Solid Cancers. Genes Chromosomes Cancer 2008;47:102537. [PubMed: 18709663]

43. Yi S, Tsao MS. Activation of hepatocyte growth factor-met autocrine loop enhances tumorigenicity in a human lung adenocarcinoma cell line. Neoplasia 2000;2:226-34. [PubMed: 10935508]

44. Maulik G, Kijima T, Ma PC, Ghosh SK, Lin J, Shapiro GI, et al. Modulation of the c-Met/hepatocyte growth factor pathway in small cell lung cancer. Clin Cancer Res 2002;8:620-7. [PubMed: 11839685]

45. Jeffers M, Fiscella M, Webb CP, Anver M, Koochekpour S, Vande Woude GF. The mutationally activated Met receptor mediates motility and metastasis. Proc Natl Acad Sci U S A 1998;95:1441722. [PubMed: 9826715]

46. Derman MP, Chen JY, Spokes KC, Songyang Z, Cantley LG. An 11-amino acid sequence from cmet initiates epithelial chemotaxis via phosphatidylinositol 3-kinase and phospholipase C. J Biol Chem 1996;271:4251-5. [PubMed: 8626770]

47. Hellman A, Zlotorynski E, Scherer SW, Cheung J, Vincent JB, Smith DI, et al. A role for common fragile site induction in amplification of human oncogenes. Cancer Cell 2002;1:89-97. [PubMed: 12086891]

48. Sakakura C, Mori T, Sakabe T, Ariyama Y, Shinomiya T, Date K, et al. Gains, losses, and amplifications of genomic materials in primary gastric cancers analyzed by comparative genomic hybridization. Genes Chromosomes Cancer 1999;24:299-305. [PubMed: 10092127]

49. Smolen GA, Sordella R, Muir B, Mohapatra G, Barmettler A, Archibald H, et al. Amplification of MET may identify a subset of cancers with extreme sensitivity to the selective tyrosine kinase inhibitor PHA-665752. Proc Natl Acad Sci U S A 2006;103:2316-21. [PubMed: 16461907]

50. Jagadeeswaran R, Surawska H, Krishnaswamy S, Janamanchi V, Mackinnon AC, Seiwert TY, et al. Paxillin is a target for somatic mutations in lung cancer: implications for cell growth and invasion. Cancer Res 2008;68:132-42. [PubMed: 18172305]

51. Engelman JA, Zejnullahu K, Mitsudomi T, Song Y, Hyland C, Park JO, et al. MET amplification leads to gefitinib resistance in lung cancer by activating ERBB3 signaling. Science 2007;316:103943. [PubMed: 17463250]

52. Bean J, Brennan C, Shih JY, Riely G, Viale A, Wang L, et al. MET amplification occurs with or without T790M mutations in EGFR mutant lung tumors with acquired resistance to gefitinib or erlotinib. Proc Natl Acad Sci U S A 2007;104:20932-7. [PubMed: 18093943]

53. Schmidt L, Duh FM, Chen F, Kishida T, Glenn G, Choyke P, et al. Germline and somatic mutations in the tyrosine kinase domain of the MET proto-oncogene in papillary renal carcinomas. Nat Genet 1997;16:68-73. [PubMed: 9140397]

54. Lee JH, Han SU, Cho H, Jennings B, Gerrard B, Dean M, et al. A novel germ line juxtamembrane Met mutation in human gastric cancer. Oncogene 2000;19:4947-53. [PubMed: 11042681]

55. Liao AT, McMahon M, London CA. Identification of a novel germline MET mutation in dogs. Anim Genet 2006;37:248-52. [PubMed: 16734685]

56. Yokota S, Kiyoi H, Nakao M, Iwai T, Misawa S, Okuda T, et al. Internal tandem duplication of the FLT3 gene is preferentially seen in acute myeloid leukemia and myelodysplastic syndrome among various hematological malignancies. A study on a large series of patients and cell lines. Leukemia 1997;11:1605-9. [PubMed: 9324277]

57. Loriaux MM, Levine RL, Tyner JW, Frohling S, Scholl C, Stoffregen EP, et al. High-throughput sequence analysis of the tyrosine kinome in acute myeloid leukemia. Blood 2008;111:4788-96. [PubMed: 18252861]

58. Schmidt L, Junker K, Nakaigawa N, Kinjerski T, Weirich G, Miller M, et al. Novel mutations of the MET proto-oncogene in papillary renal carcinomas. Oncogene 1999;18:2343-50. [PubMed: 10327054]

59. Zaffaroni D, Spinola M, Galvan A, Falvella FS, Pazzaglia S, Saran A, et al. Met proto-oncogene juxtamembrane rare variations in mouse and humans: differential effects of Arg and Cys alleles on mouse lung tumorigenesis. Oncogene 2005;24:1084-90. [PubMed: 15592501] 
60. Jagadeeswaran R, Ma PC, Seiwert TY, Jagadeeswaran S, Zumba O, Nallasura V, et al. Functional analysis of c-Met/hepatocyte growth factor pathway in malignant pleural mesothelioma. Cancer Res 2006;66:352-61. [PubMed: 16397249]

61. Ma PC, Kijima T, Maulik G, Fox EA, Sattler M, Griffin JD, et al. c-MET mutaional anlysis in small cell lung cancer: Novel juxtamembrance domain mutations regulating cytoskeletal functions. Cancer Research 2003;63:6272-81. [PubMed: 14559814]

62. Jagadeeswaran R, Jagadeeswaran S, Bindokas VP, Salgia R. Activation of HGF/c-Met pathway contributes to the reactive oxygen species generation and motility of small cell lung cancer cells. Am J Physiol Lung Cell Mol Physiol 2007;292:L1488-94. [PubMed: 17322284]

63. Rodrigues MS, Reddy MM, Sattler M. Cell Cycle Regulation by Oncogenic Tyrosine Kinases in Myeloid Neoplasias: From Molecular Redox Mechanisms to Health Implications. Antioxid Redox Signal 2008;10:1813-48. [PubMed: 18593226]

64. Puri N, Ahmed S, Janamanchi V, Tretiakova M, Zumba O, Krausz T, et al. c-Met is a potentially new therapeutic target for treatment of human melanoma. Clin Cancer Res 2007;13:2246-53. [PubMed: 17404109]

65. Peschard P, Fournier TM, Lamorte L, Naujokas MA, Band H, Langdon WY, et al. Mutation of the c-Cbl TKB domain binding site on the Met receptor tyrosine kinase converts it into a transforming protein. Mol Cell 2001;8:995-1004. [PubMed: 11741535]

66. Kong-Beltran M, Stamos J, Wickramasinghe D. The Sema domain of Met is necessary for receptor dimerization and activation. Cancer Cell 2004;6:75-84. [PubMed: 15261143]

67. Johnson L, Mercer K, Greenbaum D, Bronson RT, Crowley D, Tuveson DA, et al. Somatic activation of the K-ras oncogene causes early onset lung cancer in mice. Nature 2001;410:1111-6. [PubMed: 11323676]

68. Yang Y, Wislez M, Fujimoto N, Prudkin L, Izzo JG, Uno F, et al. A selective small molecule inhibitor of c-Met, PHA-665752, reverses lung premalignancy induced by mutant K-ras. Mol Cancer Ther 2008;7:952-60. [PubMed: 18413809]

69. Salgia R, Skarin AT. Molecular abnormalities in lung cancer. J Clin Oncol 1998;16:1207-17. [PubMed: 9508209]

70. Feng Z, Li W, Ward A, Piggott BJ, Larkspur ER, Sternberg PW, et al. A C. elegans model of nicotinedependent behavior: regulation by TRP-family channels. Cell 2006;127:621-33. [PubMed: 17081982]

71. Siddiqui SS, Loganathan S, Krishnaswamy S, Faoro L, Jagadeeswaran R, Salgia R. C. elegans as a model organism for in vivo screening in cancer: effects of human c-Met in lung cancer affect $\mathrm{C}$. elegans vulva phenotypes. Cancer Biol Ther 2008;7:856-63. [PubMed: 18340114]

72. Bardelli A, Longati P, Williams TA, Benvenuti S, Comoglio PM. A peptide representing the carboxylterminal tail of the met receptor inhibits kinase activity and invasive growth. J Biol Chem 1999;274:29274-81. [PubMed: 10506185]

73. Christensen JK, Schreck R, Burrows J, Kuruganti P, Chan E, Le P, et al. A selective small molecule inhibitor of c-Met kinase inhibits c-Met-dependent phenotypes in vitro and exhibits cytoreductive anti-tumor activity in vivo. Cancer Research 2003;63:7345-55. [PubMed: 14612533]

74. Cassinelli G, Lanzi C, Petrangolini G, Tortoreto M, Pratesi G, Cuccuru G, et al. Inhibition of c-Met and prevention of spontaneous metastatic spreading by the 2-indolinone RPI-1. Mol Cancer Ther 2006;5:2388-97. [PubMed: 16985073]

75. Sattler M, Pride YB, Ma P, Gramlich JL, Chu SC, Quinnan LA, et al. A novel small molecule met inhibitor induces apoptosis in cells transformed by the oncogenic TPR-MET tyrosine kinase. Cancer Res 2003;63:5462-9. [PubMed: 14500382]

76. Zou HY, Li Q, Lee JH, Arango ME, McDonnell SR, Yamazaki S, et al. An orally available smallmolecule inhibitor of c-Met, PF-2341066, exhibits cytoreductive antitumor efficacy through antiproliferative and antiangiogenic mechanisms. Cancer Res 2007;67:4408-17. [PubMed: 17483355]

77. Morotti A, Mila S, Accornero P, Tagliabue E, Ponzetto C. K252a inhibits the oncogenic properties of Met, the HGF receptor. Oncogene 2002;21:4885-93. [PubMed: 12118367]

78. Walz C, Sattler M. Novel targeted therapies to overcome imatinib mesylate resistance in chronic myeloid leukemia (CML). Crit Rev Oncol Hematol 2006;57:145-64. [PubMed: 16213151] 
79. Yap, TA.; Barriuso, J.; Frentzas, S.; Riisnaes, R.; Clark, J.; Dukes, J., et al. Pharmacokinetic (PK) and pharmacodynamic (PD) phase I study of an oral c-Met inhibitor ARQ197 386 reaches maximum tolerated dose (MTD) in a twice daily (bid) dosing schedule; Paper presented at 20th EORTC-NCIAACR symposium October, 2008; Geneva, Switzerland. 2008.

80. Salgia, R.; Peterson, A.; Eppler, S.; Yu, W.; Polite, B.; Geary, D., et al. A phase I, open-label, doseescalation study of the safety and pharmacology of MetMAb, a monovalent antagonist antibody to the receptor c-Met, administered IV in patients with locally advanced or metastatic solid tumors; Paper presented at 20th EORTC-NCI-AACR symposium October, 2008; Geneva, Switzerland. 2008.

81. Date K, Matsumoto K, Shimura H, Tanaka M, Nakamura T. HGF/NK4 is a specific antagonist for pleiotrophic actions of hepatocyte growth factor. FEBS Lett 1997;420:1-6. [PubMed: 9450538]

82. Matsumoto K, Nakamura T. NK4 gene therapy targeting HGF-Met and angiogenesis. Front Biosci 2008;13:1943-51. [PubMed: 17981681]

83. Tomioka D, Maehara N, Kuba K, Mizumoto K, Tanaka M, Matsumoto K, et al. Inhibition of growth, invasion, and metastasis of human pancreatic carcinoma cells by NK4 in an orthotopic mouse model. Cancer Res 2001;61:7518-24. [PubMed: 11606388]

84. Parr C, Hiscox S, Nakamura T, Matsumoto K, Jiang WG. Nk4, a new HGF/SF variant, is an antagonist to the influence of $\mathrm{HGF} / \mathrm{SF}$ on the motility and invasion of colon cancer cells. Int J Cancer 2000;85:563-70. [PubMed: 10699931]

85. Martens T, Schmidt NO, Eckerich C, Fillbrandt R, Merchant M, Schwall R, et al. A novel one-armed anti-c-Met antibody inhibits glioblastoma growth in vivo. Clin Cancer Res 2006;12:6144-52. [PubMed: 17062691]

86. Michieli P, Basilico C, Pennacchietti S, Maffe A, Tamagnone L, Giordano S, et al. Mutant Metmediated transformation is ligand-dependent and can be inhibited by HGF antagonists. Oncogene 1999;18:5221-31. [PubMed: 10498872]

87. Michieli P, Mazzone M, Basilico C, Cavassa S, Sottile A, Naldini L, et al. Targeting the tumor and its microenvironment by a dual-function decoy Met receptor. Cancer Cell 2004;6:61-73. [PubMed: 15261142]

88. Tseng JR, Kang KW, Dandekar M, Yaghoubi S, Lee JH, Christensen JG, et al. Preclinical efficacy of the c-Met inhibitor CE-355621 in a U87 MG mouse xenograft model evaluated by 18F-FDG smallanimal PET. J Nucl Med 2008;49:129-34. [PubMed: 18077531]

89. Jun HT, Sun J, Rex K, Radinsky R, Kendall R, Coxon A, et al. AMG 102, a fully human antihepatocyte growth factor/scatter factor neutralizing antibody, enhances the efficacy of temozolomide or docetaxel in U-87 MG cells and xenografts. Clin Cancer Res 2007;13:6735-42. [PubMed: 18006775]

90. Dassonville O, Bozec A, Fischel JL, Milano G. EGFR targeting therapies: monoclonal antibodies versus tyrosine kinase inhibitors. Similarities and differences. Crit Rev Oncol Hematol 2007;62:5361. [PubMed: 17324578]

91. Dalmay T, Edwards DR. MicroRNAs and the hallmarks of cancer. Oncogene 2006;25:6170-5. [PubMed: 17028596]

92. Herynk MH, Stoeltzing O, Reinmuth N, Parikh NU, Abounader R, Laterra J, et al. Down-regulation of c-Met inhibits growth in the liver of human colorectal carcinoma cells. Cancer Res 2003;63:29906. [PubMed: 12782608]

93. Stellrecht CM, Phillip CJ, Cervantes-Gomez F, Gandhi V. Multiple myeloma cell killing by depletion of the MET receptor tyrosine kinase. Cancer Res 2007;67:9913-20. [PubMed: 17942923]

94. Shinomiya N, Gao CF, Xie Q, Gustafson M, Waters DJ, Zhang YW, et al. RNA interference reveals that ligand-independent met activity is required for tumor cell signaling and survival. Cancer Res 2004;64:7962-70. [PubMed: 15520203]

95. Lutterbach B, Zeng Q, Davis LJ, Hatch H, Hang G, Kohl NE, et al. Lung cancer cell lines harboring MET gene amplification are dependent on Met for growth and survival. Cancer Res 2007;67:20818. [PubMed: 17332337]

96. Kamal A, Thao L, Sensintaffar J, Zhang L, Boehm MF, Fritz LC, et al. A high-affinity conformation of Hsp90 confers tumour selectivity on Hsp90 inhibitors. Nature 2003;425:407-10. [PubMed: 14508491] 
97. Webb CP, Hose CD, Koochekpour S, Jeffers M, Oskarsson M, Sausville E, et al. The geldanamycins are potent inhibitors of the hepatocyte growth factor/scatter factor-met-urokinase plasminogen activator-plasmin proteolytic network. Cancer Res 2000;60:342-9. [PubMed: 10667586]

98. Xie Q, Gao CF, Shinomiya N, Sausville E, Hay R, Gustafson M, et al. Geldanamycins exquisitely inhibit HGF/SF-mediated tumor cell invasion. Oncogene 2005;24:3697-707. [PubMed: 15782129]

99. Jin H, Yang R, Zheng Z, Romero M, Ross J, Bou-Reslan H, et al. MetMAb, the one-armed 5D5 antic-Met antibody, inhibits orthotopic pancreatic tumor growth and improves survival. Cancer Res 2008;68:4360-8. [PubMed: 18519697]

100. Garcia A, Rosen L, Cunningham CC, Nemunaitis J, Li C, Rulewski N, et al. Phase 1 study of ARQ 197 , a selective inhibitor of the c-Met RTK in patients with metastatic solid tumors reaches recommended phase 2 dose. J Clin Oncol 2007;25 June 20 suppl; abstr 3525.

101. Camacho LH, Moulder SL, LoRusso PM, Blumenschein GR, Bristow PJ, Kurzrock R, et al. First in human phase I study of MK-2461, a small molecule inhibitor of c-Met, for patients with advanced solid tumors. J Clin Oncol 2008;26 May 20 suppl; abstr 14657.

102. Mahadevan D, Cooke L, Riley C, Swart R, Simons B, Della Croce K, et al. A novel tyrosine kinase switch is a mechanism of imatinib resistance in gastrointestinal stromal tumors. Oncogene 2007;26:3909-19. [PubMed: 17325667]

103. Christensen JG, Zou HY, Arango ME, Li Q, Lee JH, McDonnell SR, et al. Cytoreductive antitumor activity of PF-2341066, a novel inhibitor of anaplastic lymphoma kinase and c-Met, in experimental models of anaplastic large-cell lymphoma. Mol Cancer Ther 2007;6:3314-22. [PubMed: 18089725]

104. Salgia R, Sherman S, Hong DS, Ng CS, Frye J, Janisch L, et al. A phase I study of XL184, a RET, VEGFR2, and MET kinase inhibitor, in patients (pts) with advanced malignancies, including pts with medullary thyroid cancer (MTC). J Clin Oncol 2007;26 May 20 suppl; abstr 3522. 


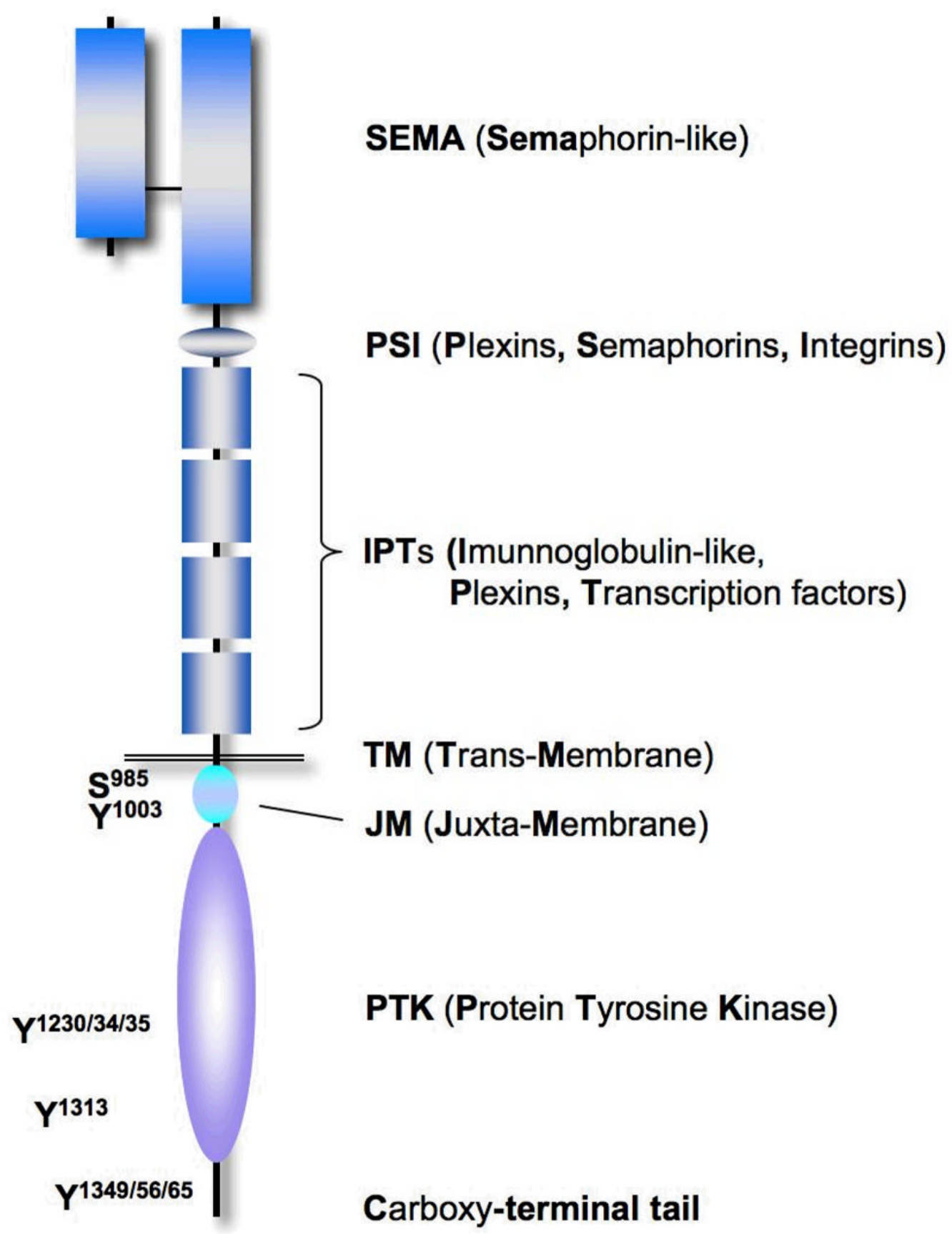

Figure 1. The functional domains of MET

The sema domain (semaphorin-like), the PSI domain (found in plexins, semaphorins, and integrins), the IPT repeat domains (found in Ig-like regions, plexins and transcription factors), the trans-membrane (TM) domain, juxta-membrane (JM) domain, the tyrosine kinase domain and various phosphorylation sites (P) important for cellular functions are shown. 


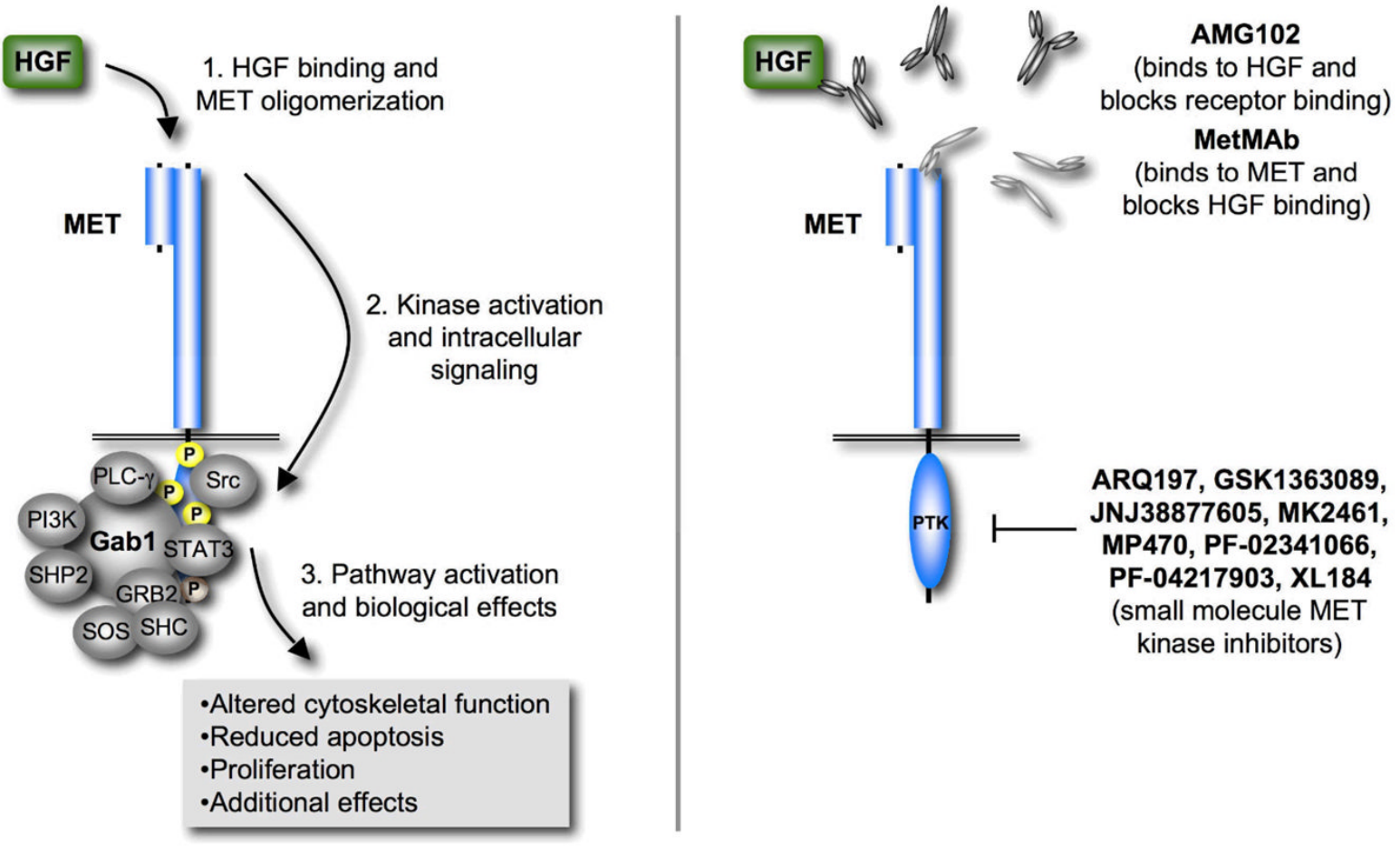

Figure 2. Current clinical approaches for the targeting of the HGF/MET pathway

HGF-dependent activation of the MET pathway can be disrupted through extracellular therapies that interfere with HGF binding to MET. Intracellular approaches can attenuate or inhibit HGF dependent and independent mechanisms that lead to phosphorylation of MET kinase substrates. 
Table 1

HGF and MET inhibitor under clinical evaluation.

\begin{tabular}{|c|c|}
\hline $\begin{array}{l}\text { Experimental Drug } \\
\text { (Drug Maker) }\end{array}$ & $\begin{array}{l}\text { Spectrum of Targets * } \\
\text { (Clinical Application) }\end{array}$ \\
\hline \multicolumn{2}{|c|}{ Monoclonal Anti-HGF Antibodies } \\
\hline $\begin{array}{l}\text { AMG102 } \\
\text { (Amgen) }\end{array}$ & $\begin{array}{l}\text { A human IgG2 monoclonal antibody against HGF that prevents receptor binding. } \\
\text { [89] } \\
\text { (Malignant glioma, renal cell carcinoma, gastric or esophagogastric junction } \\
\text { cancer) }\end{array}$ \\
\hline \multicolumn{2}{|c|}{ Monoclonal Anti-Met Antibodies } \\
\hline $\begin{array}{l}\text { MetMAb } \\
\text { (Genentech) }\end{array}$ & $\begin{array}{l}\text { A monovalent HGF antagonist antibody against MET }[85,99] \\
\text { (Advanced and metastatic solid tumors) }\end{array}$ \\
\hline \multicolumn{2}{|c|}{$\underline{\text { Small Molecule MET Inhibitors }}$} \\
\hline $\begin{array}{l}\text { ARQ197 } \\
\text { (ArQule) }\end{array}$ & $\begin{array}{l}\text { A selective MET tyrosine kinase inhibitor [100] } \\
\text { (Pancreatic neoplasms, microphthalmia transcription factor associated tumors, } \\
\text { alveolar soft part sarcoma, clear cell sarcoma, renal cell carcinoma, and other solid } \\
\text { tumors) }\end{array}$ \\
\hline $\begin{array}{l}\text { GSK1363089 (XL880) } \\
\text { (GlaxoSmithKline) }\end{array}$ & $\begin{array}{l}\text { Broad spectrum tyrosine kinase inhibitor (MET, VEGFR2, PDGFRß, KIT, FLT3, } \\
\text { TIE2, RON) [52] } \\
\text { (Treatment of squamous cell carcinoma, gastric cancer, papillary renal cell } \\
\text { carcinoma, and other solid tumors) }\end{array}$ \\
\hline $\begin{array}{l}\text { JNJ38877605 } \\
\text { (Johnson \& Johnson) }\end{array}$ & $\begin{array}{l}\text { A selective MET tyrosine kinase inhibitor } \\
\text { (Solid tumors) }\end{array}$ \\
\hline $\begin{array}{l}\text { MK2461 } \\
\text { (Merck) }\end{array}$ & $\begin{array}{l}\text { A small molecule inhibitor of MET [101] } \\
\text { (Solid tumors) }\end{array}$ \\
\hline $\begin{array}{l}\text { MP470 } \\
\text { (SuperGen) }\end{array}$ & $\begin{array}{l}\text { A multi-targeted inhibitor of MET, RET, KIT, AXL, PDGFR } \alpha \text { and FLT3. MP470 } \\
\text { also suppresses the DNA repair protein Rad51 through an unknown mechanism. } \\
{[102]} \\
\text { (Solid tumor, Hodgkin's lymphoma, or non-Hodgkin's lymphoma) }\end{array}$ \\
\hline $\begin{array}{l}\text { PF-02341066 } \\
\text { (Pfizer) }\end{array}$ & $\begin{array}{l}\text { A MET and ALK kinase inhibitor [76,103] } \\
\text { (Systemic Anaplastic Large-Cell Lymphoma and other malignancies, except } \\
\text { leukemias) }\end{array}$ \\
\hline $\begin{array}{l}\text { PF-04217903 } \\
\text { (Pfizer) }\end{array}$ & $\begin{array}{l}\text { A MET kinase inhibitor [103] } \\
\text { (Solid tumors) }\end{array}$ \\
\hline $\begin{array}{l}\text { XL184 } \\
\text { (Exelixis) }\end{array}$ & $\begin{array}{l}\text { A MET, VEGFR2, and RET small molecule inhibitor [104] } \\
\text { (Medullary thyroid cancer, non-small-cell lung cancer, lymphoma, thyroid cancer, } \\
\text { glioblastoma multiforme, and other malignancies) }\end{array}$ \\
\hline
\end{tabular}

